\title{
THE DUAL CHALLENGE OF DEMOCRATISATION AND EUROPEAN INTEGRATION IN POST-COMMUNIST POLAND
}

\author{
Gary CHAMBERS ${ }^{*}$
}

\section{Abstract:}

Post-communist Poland has simultaneously undertaken major political and economic reforms and entered the European Union. At the same time, Poland has witnessed significant party instability, electoral volatility and the evolution of unorthodox populist movements and parties in the course of democratisation transition since 1989. Indeed, the electoral successes of a variety of Eurosceptic, socially conservative and devoutly Catholic political parties supported by a 'coalition of the politically and economically dispossessed' in 2005 poses a far reaching challenge to the Polish political order itself and even to the ambitions of European political elites. The aim of this article is to analyse the key aspects of democratic transformation since 1989 and to locate therein both the factors that have impeded the development of democratic consolidation as well as to map the cumulative effect of the European Union accession process on the character of recent Polish politics. Only against such a background will it be possible to discern the possible trajectory of the Polish political order and speculate on the shape of Polish-EU relations in the years ahead.

Keywords: Poland, Democratisation,European Union, Populism, PolishEU relations.

$\ddot{O}_{\text {zet: }}$

Polonya, komünizm sonrasinda önemli siyasi ve ekonomik reformlar yaşamaya başlamıştır. Bu sırada Avrupa Biriliği'nde de yerini almıştır. Bunun yant sira Polonya, 1989'den bu yana demokratikleşme hareketleri boyunca süre gelen ciddi parti istikrarsizliklarına, seçimle ilgili gelgitlere ve alışılmışın olmayan halkçı kesim hareketlerinde ve partilerinde meydana

* Dr, Marmara University, Atatürk Education Faculty 
gelen evrimleşmeye tantklık etmiştir. 2005 yılında "siyasi ve ekonomik olarak mal varlılı̆̆ına el konulmuş kişilerin oluşturduğu bir birlik" tarafindan desteklenen gruplar, Katolik muhafazakarların oluşturduğu toplumsal olarak tutucu sosyal partilerdir. Bu partiler, Avrupa'yı kuşkulu gözlerle takip etmekte, Polonya'nın siyasi düzeni ve hatta Avrupa'nın "elit" olarak bilinen siyasi seçkin grubunun ihtiraslarına bile günden güne artan meydan okuma tavrlyla yaklaşmaktadırlar. Bu makalenin amacı ise 1989'dan beri gerçekleşen demokrasi geçişinin kilit noktalarını incelemek ve Avrupa Birliği'ne geçiş sürecinin Polonya'nın son zamanlardaki siyasi niteliği üzerindeki birikimsel etkisinin haritasını çıkarmaktır. Bu hususta demokratikleşme nin gelişimini engelleyen her iki etkenin de sintrları çizilecektir. Polonya siyasi düzeninin çizeceği mümkün yolların farkında olmak ve Polonya-AB'nin gelecek yıllardaki ilişkilerine dair tahminlerde bulunmak ancak böyle bir art alan bilgisi sayesinde mümkün olacaktır.

Anahtar kelimeler: Polonya, Demokratikleşme, Avrupa Biriliği, Populizm, Polonya-AB ilişkileri.

\section{Introduction}

The aim of this article is to identify the problems of democratic consolidation in post-1989 Poland and to consider the future prospects of Polish democracy now that the country has regained a full role in the European political and economic space. The article will attempt to demonstrate, as Munck and Skalnik (1999) have argued, that the mode of a country's democratic transition is likely to have distinct consequences for the form of a posttransitional regime and politics through its influence on the pattern of elite competition, and the choice of particular institutional rules that define the prospects for regime consolidation.

Dahrendorf (1997:12) was perhaps justified in arguing that 'the revolution of 1989 , like other revolutions before it, was bound to disappoint those who entered it with extravagant hopes for a new world of unconstrained discourse, equality and fundamental democracy'. While the Polish peoples's commitment to democracy as a regime is indisputable, generalised concern at the social costs of economic dislocation, privatisation and marketisation, the problem of corruption in political and economic elites and a desire to retaliate against governing parties at the ballot box, have produced less than ideal conditions in which political stability might develop. Poland's transition has been marked by the emergence and increasing political mobilisation of extreme populist movements and parties 
articulating criticism of the existing institutions of representative democracy, a failure to develop a stable party system and a political discourse that still tends to be excessively structured in terms of moralcultural issues and/or political geneaology. Indeed, two populist parties, the radical-agrarian Self-Defence of the Republic of Poland (Samoobrona Rzeczypospolitej Polskiej) and the Catholic-nationalist League of Polish Families (Liga Polskich Rodzin) are now in a controversial government coalition with the more traditional conservative Law and Justice party (Prawo i Sprawiedliwość) which itself has been prone to populist tendencies. Pop-Eleches (2001:31-2) has warned that if the benefits of economic and political reforms continue to elude large parts of a population, a continued electoral ascendancy of 'assorted' unorthodox parties or the increasing temptation of orthodox political parties to resort to opportunistic electoral appeals to prevent further inroads will become inevitable. Thus, populism is 'the pathology of democracy' (Meny and Surel, 2002:3).

In the Polish case, the mode of democratic transition combined with multiple sources of socio-economic friction made it highly improbable that Poland's entry to the EU would be one entailing smooth adjustment. The adaption of candidate countries to EU negotiating demands, the institutionlisation of EU rules, policy paradigms and norms - the 'downloading' of EU policy into the national polity as Grabbe (2006:4) has described it- prior to 2004 introduced significant strains into domestic political orders already preoccupied with the wider processes of developing post-communist political systems and economies. Poland's negotiations to join the EU opened in 1998 and often proceded in a slow and distinctly confrontational fashion, provoked distinctly Eurosceptic reactions at the mass and elite levels and a sense that EU membership would likely deliver much less than was once hoped. As Cas Mudde (2004:2) has observed, the stereotypical picture of the EU in many of the 2004 Central and Eastern European entrants '... has changed from a rich and democratic paradise into a meddlesome and selfish bureaucratic behemoth...'. In Poland, Eurosceptic and anti-EU parties have made electoral gains with objections to the terms and conditions of EU entry and fears that Poland's recently acquired sovereignty and cultural distinctiveness will be eroded by EU membership. This article will attempt to survey the influence of the EU accession question on Polish political discourse and its contribution to party-based populist sentiment and Euroscepticism. In this regard, it is also appropriate to consider how domestic political pressures in Poland are likely to affect both the country's relationship with the EU (in the sense of how the country accommodates EU policy and institutional models) and more generally in 
relation to how the Polish position on EU matters may impact on the wider processes of European integration. In short, will the current political constellation in Poland always be prepared to play by EU rules?

The first section of this article attempts to map the transition to democratisation in Poland since 1989 and to outline the problems that have arisen in the development of stable party systems in Poland. The second part of the article attempts to identify the impact that the issue of European Union accession has exerted on the evolving Polish political order. Thirdly, the policy choices of the current Polish government are considered with special reference to both domestic political developments in Poland and the country's foreign policy, particularly with regard to Poland's-European Union relations where tension seems to be increasing.

Arguably, an understanding of the Polish case, then, illuminates the distinctive challenges new democracies face when they try to consolidate themselves. These challenges are all the more distinctive when adaption and accession to the $\mathrm{EU}$ are at issue.

\section{An overview of the Polish Reform Process}

The following discussion will attempt to demonstrate that the transition from a totalitarian communist regime to political pluralism in post-1989 Poland has been complex and fractious. The Roundtable agreement between the incumbent communist government and the labour-based social movement Solidarity led to partially free elections in June 1989 (opposition participation in elections, however, was restricted to a mere 35 percent of the seats in the pivotal lower house) and the formation of the first nonCommunist government in the Soviet bloc. Poland emerged from its transition with a fully competitive democracy, but the capacity of the old elites to determine the initial roundtable breakthrough and their continued engagement in the demócratization process impeded a definitive break with the past (Munck and Skalnik, 1999:247-8). It is increasingly apparent that the negotiated transition from communism has generated many negative effects not least in developing a climate of moral complicity between segments of the anti-communist opposition and communist elites (Surdej, 2005: 17-8).

Thus, perhaps inevitably, Poland has one of the lowest election turnout rates in Europe, while research and opinion polls display a combination of a lack of interest in politics and a deep mistrust in politicians (Kochanowicz, Kozarzewski, Woodward, 1999:8). The identities of Polish political parties are elusive and these parties are not successful at representing social 
interests well (Grabowska and Szawiel, 2001). In other words, political parties in Poland do not perform the normal functions expected of parties in a mature democracy (Cave, 2001). Indeed, Pridham and Lewis (cited in Holmes 1998) refrain from referring to the situation in Polish politics as a 'party system', believing instead that it is to be evaluated as an emerging system, the nature of which has still to be defined. It is indisputable that Polish political parties lack the deep roots and mass memberships found in many Western European countries. They can be represented as shifting coalitions with indistinct profiles (Lucas, 2006). Weak internal structures contribute to poor party discipline and make the Polish political scene transitory in nature (Cave, 2000).

\section{1. "Shock Therapy" and the Return of the Centre-Left}

After the Roundtable negotiations of 1989, Poland was governed until 1991 by governments that either contained purely some degree of communist representation and their former coalition partners or else tended to be technocratic in nature. Poland's first entirely free election in 1991 saw the participation of more than 100 parties with no party receiving more than $13 \%$ of the total vote, thereby producing a severely fragmented parliament. This fragmentation inevitably produced a succession of short-lived governments between 1991-93 from centre and centre-right parties that had emerged from the Solidarity opposition movement. From its earliest years, Solidarity had always been an amalgam of conflicting influences: workers' rights, Catholic nationalism and westernising liberalism, amongst others united only in opposition to communism. During the post-1989 period, the post-Solidarity movement, however, proved completely unable to transform itself from an amorphous social movement into a mature political construct and disintegrated into several warring factions. Clearly, the post-Solidarity movement was fatally debilitated by the absence of a coherent political programme with which to navigate the transition period. The transition itself necessitated far-reaching and often painful structural change in the economy. In January 1990, Deputy Prime Minister Leszek Balcerowicz introduced a programme of fast and deep reforms, sometimes known as 'shock therapy', designed to end hyperinflation and facilitate the development of a market economy. The Balcerowicz plan rapidly and drastically reduced the state's influence over the Polish economy. As Klich (1997:8-9) has pointed out, while in December 1989 the number of registered unemployed was $0.3 \%$ of the labour force, in December 1990 this ratio had reached $6.5 \%$ to increase at the end of 1991 to $11.9 \%(2.16 \mathrm{~m}$ people). The unemployment rate reached its highest in $1993(16.4 \%$ or $2.89 \mathrm{~m}$ ). The broader social and economic benefits of this reform process 
'... were much less tangible and slower to materialize than the reformers had hoped for, with inflation remaining extremely high and the economy moving into a sharp crisis...' (Szczerbiak, 2002:3).

The sudden introduction of liberal macro-economic reforms and their consequences - mass unemployment, a fall in real incomes, and reductions in the social security net- combined with endemic instability on the centreright resulted in the electoral victory of the revamped social democratic Democratic Left Alliance (Sojusz Lewicy Demokratycznej, SLD) in 1993. The SLD had its organisational roots in the Polska Zjednoczona Partia Robotnicza, PZPR- the now defunct Polish Communist Party. The Polish Peasant's Party (Polskie Stronnictwo Ludowe, PSL) formed in 1990 emerged as the second largest party in the 1993 election and was the junior government coalition partner between 1993-97. The party which was the successor to the former communist satellite, the United Peasants Party, is one of the few parties in Poland with a clearly defined electorate. The PSL opposed the economic reforms and campaigned strongly in favour of continued subsidies for state-owned farms. In spite of the campaign against the economic reforms and the need for state intervention to protect Poland's heavy industry which the SLD had advocated in opposition, the SLD-PSL government essentially maintained the pro-market reform strategy as well as maintaining policies of social liberalism. Indeed, the SLD-PSL government systematically reaped the political benefits of the reforms in 1995-1997, when annual GDP growth ranged from $6 \%$ to almost $7 \%$, and the unemployment rate fell from more than 16 percent in 1994 to below 10 percent by 1998 as reported by Dabrowski, Rohozynsky, and Sinitsina (2004:2-3). However, economic growth was unevenly distributed and a significant pattern of rural-urban inequality emerged. This inequality was also reflected in the growing differentiation within the urban population, as vulnerable groups found their material position deteriorating. The social democrat-peasant coalition of 1993-7 was reconstituted three times under successive prime ministers, and for the first two years it faced an openly hostile president in former Solidarity leader Lech Walesa. Relations between the two coalition partners were often ill tempered undermining the cohesion of government and preventing much needed administrative reform altogether (Millerd,2002). Indeed, the SLD's definitive victory was followed by very little action in confronting the underlying divisions of Polish society. During the four years of the SLD-PSL government, credible centre-right parties had no presence in parliament whatsoever due to Solidarity's electoral and organisational collapse, and 'few expected the right to regroup in time for the 1997 parliamentary elections'(Matraszek, 
2005:88). The extent of the divisions in the centre-right became apparent in 1993, when right-wing politicians attempted to find a single candidate acceptable to the entire right. In the end, however, seven campaigned for the presidency, four of them withdrawing before the first round had even been held.

\subsection{The Centre-right Revives?}

By 1997, public support for the SLD-PSL government had effectively collapsed due to a number of diverse factors. The government was criticized by economic liberals for failing to deepen structural reforms or use economic growth to permit cuts in taxation and longer-term fiscal stability (Szczerbiak, 2002:3). Another factor was the so-called Oleksy spy scandal of 1995-67 when serving SDL prime minister Jozef Oleksky was accused by the Walesa-appointed minister of the interior, Andrzej Milczanowski, of long-time collaboration with Soviet and later Russian intelligence. Oleksy was forced to resign over the allegations in 1996, although an investigation by a military procurator presented no charges. The Oleksy issue became a salient feature of the next election campaign, allowing the opposition to portray the SDL as representing a threat to Poland. In June 1996, Solidarity Election Action, (Akcja Wyborcza Solidarnosc, AWS) was established as a vehicle to overcome the divisiveness and antagonisms on the right that had underpinned the 1993 parliamentary defeat and even more painfully the Presidential debacle of 1995 , both of which were caused by ' .... an inability to compromise...' as noted by the International Republican Institute (1997:1). The AWS was not a formally constituted political party but rather a fragile alliance of the Solidarity trade union together with thirty-eight liberal, conservative and Christian democratic parties and groupings led by the Solidarity trade union and its leader Marian Krzaklewski. Solidarity was the biggest grouping within the AWS. The Christian National Union $(\mathrm{ZChN})$, a nationalistic Catholic party, and the Conservative Peasants Party (SKL) were also major components within the AWS. In the September 1997 elections, AWS obtained 201 parliamentary seats, the SLD 164, with 60 seats going to the centrist Freedom Union (UW), 27 to the Polish Peasant Party (PSL) and 6 to the far- right Movement for the Reconstruction of Poland, Ruch Odbudowy Polski (ROP), a vehement critic of both the SLD and the Freedom Union.While some in the AWS would have prefered a more socially conservative coalition with the ROP and PSL, the AWS leadership opted to form a coalition government with the UW as its junior party. Despite his strong political position, Krzaklewski decided not to enter the cabinet.The UW, a strongly pro-market party was led by Leszek Balcerowicz, the architect of the 1990-91 economic reform plan, who now 
returned to the finance ministry. The Freedom Union (UW) itself evolved from the union with the party of the first non-communist Polish prime minister after World War II, Tadeusz Mazowiecki, and the LiberalDemocratic Congress originally associated with Lech Wałesa. Almost from the outset, the government was marked by turbulent internal disputes: the UW was innately suspicious of the trade union influence in the AWS and its populist economic proposals while the AWS were far more critical of the rigorous economic reforms advocated by the UW. This mutual mistrust led to the formation of a technocratic government filled by AWS-supported nominees. Jerzy Buzek, a loyal political ally of Marian Krzaklewski was chosen to be a compromise candidate prime minister. The AWS-UW government's accelerated programme of reforms in local and regional administration, the pension system, education and health care proved to be unpopular and poorly executed (Szczerbiak, 2002:3). The governing parties AWS and the UW clashed openly, parliamentary discipline was almost completely lacking, ministers defied their own government, and political leadership was notable by its absence (Millerd 2002). The real source of difficulty within the Burzek government was not so much the tension between the AWS and UW but the much deeper animosities within the AWS itself. The AWS essentially became a federation of competing cliques and parties which lacked a strong leadership willing to institute an effective mechanism to instill party discipline (Matraszek, 2005:94-5). By May 2000, the UW had become increasingly marginalized and finally departed the government seeking to distance itself from a deeply unpopular government. The Buzek government was perceived to be incompetent, divided, and mired in a series of corruption scandals that damaged the credibility of the centre right as a whole. At the same time, GDP growth declined to $1.1 \%$ in 2001 and there was a sharp increase in the budget deficit, which in 2001 amounted to 5.5\% of GDP. The unemployment rate increased in 2000-2001 and became the highest in Europe at $17.4 \%$ as of the end of 2001 Szczerbiak (2002:3) and Kochanowicz, Kozarzewski, Woodward (2005:53-4 ).

\subsection{Implosion of the Centre-Right}

The implosion of the AWS accelerated when Marian Krzaklewski made the ill-considered decision to stand for president against popular incumbent Aleksander Kwasniewski in the presidential election of October 2000. Krzaklewski suffered a first round defeat to the incumbent, coming third behind independent candidate Andrzej Olechowski.,and in the process gaining nearly three times fewer votes than his party in the 1997 parliamentary elections; half the electorate that supported AWS in 1997 stayed home or drifted to other candidates (Majman,2000). The process of 
AWS disintegration continued rapidly in January 2001 when a new party the Civic Platform (Platforma Obywatelska) PO was formed by Donald Tusk, Deputy Senate speaker and former UW leader, Andrez Olechowski, the independent candidate for president in 1995, and Maciej Plazynsky, Sejm speaker and one of the AWS leaders. Olechowski claimed that the new formation wanted '... to release the energy of all Poles and of our democracy, which is tied up by corruption, incompetence and the unclear role of the trade unions' said (Kość:2001).

The OP positioned itself as a liberal conservative movement that could appeal to centrist-minded AWS voters; in favour of flat taxes and flexible labour markets and against a seemingly corrupt establishment. The AWS faced further marginalization in the Summer of 2001 when Justice Minister Lech Kaczynski, left the AWS to support the Law and Justice Party (Prawo i Sprawiedliwość, PiS) formally established by his brother Jaroslaw Kaczynski, an AWS deputy. The PiS was culturally conservative while socially welfarist with demonstrably less enthusiasm for the type of liberal economic reforms advocated by the PO.

As the AWS decomposed, the PO and the PiS converged (although not in any organisational sense) in terms of a commitment to competence and probity in public life, distinctive policy alternatives to the SLD, and a deeply-held suspicion of the Solidarity movement (which formally withdrew itself from active party politics in the spring of 2001). The SLD, on the other hand, had successfully stabilized itself as a centrist and unified opposition under the disciplined leadership of the former communist Politburo member Leszek Miller, who had been elected as Chairman of the SLD in December 1999. The September 2001 elections resulted in victory for the left-wing coalition of the Democratic Left Alliance (SLD) and the Labour Union (UP). The UP shared most of the SLD's policy positions but was strongly anti-communist. Many of its leaders had been active dissidents under the former regime. The SLD-UP won 41.04 percent of the vote, leaving the coalition-15 seats less than a majority and was obliged to form a coalition with its former ally the PSL. Both the AWS and the UW remained outside of parliament failing to reach the five per cent threshold for entry compared to the PO which came second to the SLD with $12.68 \%$ of the vote and $9.50 \%$ for the PiS.

The 2001 election, however, signalled a final rupture with the notion that the Polish right should continue to be dominated by the ethos of the Solidarity trade union movement. The most dramatic outcome of the election was that nearly a fifth of the electorate had voted for nationalist, 
xenophobic or extremist parties. The radical farmers' union Samoobrona, which took 10.2 percent of the vote and 53 seats came third in the election. Samoobrona had evolved from the agrarian trade union movement led by the charismatic Andrez Lepper. A self-described 'social leftist and proud national Pole', Lepper regularly organized civil disobedience protests against governments in the 1990s to protest against what he saw as growing injustice towards farmers. Incidentally, many of Samoobrona's members hold that Jews are responsible for the economic hardships that have accompanied post-Communist reform in Poland Lepper is unembarrassed about his controversial views on democracy: '...There's too much talk about democracy - people can see it's only for elites. Only 5\% of the population have made any money out of it at the expense of all the others. People have had enough...' (Cited in Irena Maryniak, (2003). The ultra-right-wing League of Polish Families (LPR) brought up the rear with 7.87 percent of the vote and 38 seats. The LPR was formed as a coalition of various rightwing parties and clerical-nationalist groupings in the middle of 2001 and has often been compared to Jean Marie Le Pen's Front National. It has been supported by the most conservative section of the Catholic church and by its radio station, Radio Maryja. Its director, Fr Tadeusz Rydzyk has allowed the broadcast of anti-Semitic views and alleges the existence of a 'globalist mafia' conspiracy operated by liberals, Jews, Masons, journalists and foreigners. Radio Maryja, which is regularly listened to by more than a million Poles, has further expanded to include a television station, TV Trwam and a daily newspaper, Nasz Dziennik. The Vatican warned Radio Maryja in early 2006 about engaging in politics and warned Poland's Catholic hierarchy responsible for its supe-vision to safeguard the station's neutrality. More recently the radio station has been courted by Poland's governing right-wing Law and Justice (PiS) Party. Both the Samoobrona and the LPR are overwhelmingly backed by poor rural voters, particularly in the east of the country and increasingly from the industrial wastelands or peripheral cities that have declined under the free market.

\subsection{Centre-Left Consolidation and New Configurations on the Right}

After the SLD-PSL regained office in 2001, the fast growing budget defecit meant that it immediately needed to enact stringent economic austerity measures. The large tax increases and expenditure cuts that followed resulted in an unusually pronounced decline in the government's approval ratings. The success of the Miller Government in 'bringing Poland back to Europe'could hardly disguise the general failure of its domestic policies. The government achieved few notable policy successes during its period in office which was characterised by high unemployment and 
continual infighting between prime minister Miller and President Aleksander Kwasniewski. The SLD's popular base was also significantly eroded by persistent allegations of corruption, nepotism and cronyism. Szczerbiak (2006:7) cites a September 2003 poll which found most respondents considered that SLD politicians were: concerned primarily with their personal or party interests $(79 \%)$, susceptible to corruption $(75 \%)$, failed to observe the law (66\%), were dishonest $(63 \%)$ and easily embroiled in 'dubious networks' $(62 \%)$.

The post-communist left then experienced its first major rupture since 1989 when a significant faction of UP and SLD deputies established their own centre-left formation thereby depriving the government of its theoretical majority. Prime Minister Miller resigned on the 2nd May 2004, the day following Poland's accession to the EU and was eventually replaced after protracted inter-party bargaining by Marek Belka. Belka, a former SLD finance minister, headed a technocratic one-year interim government which would prepare Poland for early parliamentary elections in September 2005 and presidential elections in October 2005. The right was now resurgent, with Donald Tusk emerging as the sole leader from the Civic Platform triumvirate and benefitting from the adoption of a more nationalpatriotic discourse while Lech Kaczynski, twin brother of Jaroslaw Kaczynski, the leader of the PiS had been elected as mayor of Warsaw in October 2002. Lech Kaczynski had been a member of the Polish Parliament (1989-91), a member of the Senate (1991-93)and the Deputy Chairman of the Solidarity Trade Union, the leader of the Center Agreement Party (Porozumienie Centrum) and Security Minister in the Presidential Chancellery. He later became minister of justice and Attorney General in the Buzek government although he was not a member of any AWS associated grouping. In the September 2005 elections to the Sejm, the SLD lost 161 seats; its share of the vote fell to just $11.3 \%$. The PiS won 27 per cent of the vote, the Civic Platform (PO) took 24\%. The Samoobrona and the LPR each won $10 \%$ of the vote. The PiS and the PO, however, failed to agree on the conditions of a centre-right coalition government and the PiS governed first on its own, and then from May 2006 with the support of the populist Samoobrona and the LPR. Coalition negotiations underlined the fact that any government between the two parties would immediately be convulsed by disputes over the question of economic liberalisation and social welfare protection. In the second round of voting for the presidential election in October 2005, Lech Kaczynski polled a decisive $55 \%$ of the vote compared to $45 \%$ for Donald Tusk. It was significant that during the final week of the presidential campaign Kaczynskı charged that Tusk's 
programme represented a liberal experiment in ruthless capitalism whereas Aleksander Kwasniewski supported a solidaristic, social Poland. Alexs Szerzcbiak (2006:28-9) has argued that the 2005 parliamentary and presidential elections provide:

'tentative evidence that the 'post-communist' political divide between the 'left', associated with a more sympathetic evaluation of Communist Poland, liberal social values and secularism, and the 'right', associated with anti-communism, conservative social values and high-levels of religiosity is shifting towards a political divide structured along more conventional socio-economic lines'.

Alexs Szczerbiak (2006) has also noted that for the first time since 1989 that the same six political groupings and parties elected in 2001, all succeeded in being re-elected in the 2005 parliamentary elections. The fact that the stated aim of the PiS to introduce a 'moral renewal' and a return to traditional Catholic values would tend to undermine the notion that the old 'post-communist' political divide is about to disappear any time soon. According to Szczerbiak (2001:31) the Polish context 'left' and 'right' referred essentially to these two parties' attitudes towards the communist past and approach to moral-cultural issues (particularly the role of the Catholic Church in public life). In truth, the government has owed much of its strength to the weaknesses of the opposition parties. As Zalega, has observed (2006), '... PO, the self-appointed leader of the opposition, is undermined by its affirmed market fundamentalism... while the centre left is '... trying to establish its political presence by borrowing a Blairite social liberalism whose only effect is to isolate it from its electoral base...'

In the period between 1989 and 2001 the centre-right proved unable to evolve into a competitive election option due mainly to its heterogenous origins in the Solidarity movement and ideological inconsistencies. From 1991, Polish politics was, thus, dominated by the post-communist, Democratic Left Alliance/SLD. In 1993 and in 2001, it won the parliamentary elections and in 1995, its leader Aleksander Kwasniewski defeated Lech Walesa in presidential elections and was re-elected in 2000. In the absence of a stable party system, however, Polish politics is still very much in flux and subject to extremely high levels of electoral volatility. Whether political actors style themselves as 'left' and 'right', it would as be more appropriate as Kochanowicz, Kozarzewski and Woodward (2005:9) have advised, to distinguish four political styles in Polish politics. The first is that of commitment to a particular reform agenda, mostly characteristic of 
such parties as the UW, which has always emphasised the importance of market reforms, but also for the AWS, LPR and PiS, with their focus on the fight against former communists and defence of 'national identity'. The second style is that of effective political marketing, with a focus on opinion polls, which was characteristic of the SLD during the periods they were in power. The third style is that of clientelism and corruption, characteristic more for individuals than parties, but to which many of the parties as organizations - particularly the SLD, PSL, AWS, and Samoobrona - easily fell. The fourth is populism, of which the clearest example is Samoobrona (and perhaps also the LPR). As the International Republican Institute (1997:1 ) has correctly pointed out, while the values of a democratic form of government and (to a much more contested extent) a free market economy have been ostensibly embraced by all of the major political parties, contemporary Poland remains a country in which politics is essentially defined more by political genealogy than by subtleties in respective party platforms. In Cezary Michalski's opinion, the fate of Polish democracy will be decided by the new and deepening class divisions between those who have succeeded in finding a place for themselves in the new system, and those who have not (cited in Krasnodebski 2004). Whatever the 'styles' evident in post-1989 political life, and despite the general sentiment that the rupture with totalitarianism is definitive Plonka (2004) was unquestionably right to observe that '...the Poles often feel lost in the new reality...'.

\section{The Issue of Europe in Polish Politics}

The primary goal of Polish foreign policy post-1989 was a reorientation from Moscow and entry into key western institutions- Polish membership in NATO and the EU. ${ }^{1}$ From the very beginning of the post-communist transition, Mazowiecki and other leading Polish politicians framed the Polish-EU debate in an abstract desire for Poland to return to Europe. Foreign Minister Cimoszewicz told the Sejm in March 2002, 'For us Europe is the civilizational, economic and political necessity' (Ministry of Foreign Affairs of Poland: 2002). However, 'euro enthusiasm' was not supported by much experience or knowledge about the EU system. In December 1990, Poland submitted an application for EU association. The Solidarity-led government signed an association pact with the EU, known as a Europe Agreement, in December 1991. The Europe Agreement came into force in February 1994.The post-communist SLD-PSL coalition submitted Poland's official EU application in April 1994. Poland's application for membership

${ }^{1}$ Full membership of NATO was finally achieved in March 1999 when the Czech Republic, Poland and Hungary joined the security pact. 
was formally accepted at the Luxembourg summit in October 1994. Following the decisions of the 1997 EU Luxembourg summit, the AWS-led Buzek government formally began accession negotiations in March 1998. With some minor fluctuations, Eurobarometer polls taken throughout the1990s showed high levels of public support for EU membership in Poland (77\% per cent in June 1994, 80\% in May 1996 declining to 53\% in July 2001 before increasing to $63 \%$ in January 2003 and stabilising in the low-mid sixties ever since) (Szczerbiak, 2003:3). This level of support was paralelled by an overwhelming political elite consensus in favour of membership in the EU. However, Poland is different from the other EU member countries 'not only in size, but also in its attitudes to Europe and Europeanisation in general, and not least in the way to negotiate, which has tended to be strongly inter-governmentalist in character' (Riishoj, 2005:18).

The period from the beginning of accession negotiations in 1998 was one in which Polish discourse used to describe the EU and its institutions was hostile, even extreme, and framed in terms of 'defending national sovereignty' against Brussels (Schrijvers,2004:14). Schrijvers has argued that euro-scepticism appeared earlier in Poland than in any other CEEC due to the negative outcomes of the Europe Agreement, which had failed to link 'association' with 'membership' and generated unpopular transition reforms which were widely perceived as direct costs of EU integration. The course of the accession negotiations were complicated by difficulties in transposing the acquis communitaire into Polish law, the slow implementation of EU norms due to inadequate administrative capacity and the robust Eurosceptic line of a large faction - the Christian National Union (ZChN)- within the AWS (Szczerbiak,2002:4). The Buzek government was not, however, deterred from the objective of achieving an early date for EU accession. As both Szczerbiak (2002) and Schrijvers (2004) have noted, the beginning of the accession negotiations witnessed a politicisation of the debate on Polish EU membership focusing on the terms by which Poland would become an EU member state As the accession negotiations proceded, Poles began to realise that conforming to the requirements of membership would engender difficult economic and social consequences. As in other candidate countries, the EU also became a convenient device for Polish politicians to disguise unpopular policy prescriptions which they could claim were required by the EU.

With varying degrees of enthusiasm, the final objective of EU membership was widely supported among the main political parties and elites. Where ideological differences between political parties existed, these focused on the desirable way to reach the common goal- speed of 
integration and negotiation strategy (between those who were (allegedly) 'soft' and prepared to give in to Brussels and those who were (allegedly) in favour of a 'tough' negotiating stance in areas such as agriculture or the free movement of persons) (Wolczuk, 2001:41-4). The Buzek government announced that it would adopt a tough stance in the accession negotiations but one which, in effect, led to Poland lagging behind in closing negotiation chapters especially in 2000-2001 (Schrijvers, 2004). As Grabbe (2006:111) has observed Poland's slowness in implementing EU legislation was not always the result of a conscious strategy but originated with '...the political and institutional problems that beset Poland's policy-making apparatus for EU accession issues...' and specifically the '...fast turnover of personnel and major problems with co-ordination between the Committee for European Integration and the various line ministries...'.

\subsection{The 2003 Referendum and Polish Euroscepticism}

In 2002 and 2003 the SLD-led government accelerated the accession negotiations via a more pragmatic negotiating strategy although its PSL coalition partner remained less convinced of the potential benefits of EU membership. A 'tough' negotiating style was one not limited only to the Buzek government. The Miller government asserted itself strongly over negotiations on vote reweighting during the drafting of the Treaty of Nice through direct intervention in intra-EU negotiations (Trzaskowski,2002:18). At the Brussels summit in December 2003, Miller stubbornly refused to surrender any of the votes allocated to Poland in the Nice treaty, although they give Poland nearly as much weight as much larger Germany(Grabbe, 2004). Both the Civic Platform (PO) and the Law and Justice Party (PiS) also underlined the need for a hard line regarding European policy following the appointment of Danuta Hübner, Minister of European Affairs in Leszek Miller's government, to be the first Polish EU-commisioner, arguing that Hübner had been too 'soft' in negotiations with the EU system more serving the interests of France and Germany than Poland's (Riishoj, 2005:24). Overall, Poland adopted a resolutely inflexible stance on some of the most sensitive chapters of negotiation ( free movement of labour, capital and direct payments to farmers).

In the October 2000 presidential election, EU membership was not a major issue and eurosceptic candidates were not particularly successful in mobilising support, receiving no more than 10 per cent of the vote (Jasiewicz and Agnieska Jasiewicz-Betkiewicz, 2004:41-2). Until as recently as 2001, the issue of EU membership had limited salience in Polish election campaigns. It was only in the September 2001 parliamentary 
election that eurosceptical forces achieved significant gains. Among them were the League of Polish Families (LPR) which made its anti-EU stand the focal point of its campaign, and Self-Defence (SRP) which questioned the conditions of Poland's entry to the EU but claimed not to be opposed to the principle of EU entry. Several other parties, such as the Polish PeasantParty (PSL), the Labor Union (UP) and Law and Justice (PiS), expressed only conditional support for integration with the EU.Only two parties - the SLD and the Civic Platform - might be considered broadly pro-EU (another party of euro-enthusiasts, the Freedom Union, did not clear the 5 per- cent threshold). However, it is possible to argue that the Polish election results of 2001 should not be misinterpreted. Schrijvers (2004:14) has pointed out that the success of eurosceptic candidates represented more a protest vote against the economic mismanagement of the incumbent SLD-led government than an enhanced level of opposition among the Polish electorate. In December 2002, the Copenhagen Summit confirmed that Poland could join the EU in 2004.

In the referendum campaign of 2003, virtually the entire political establishment in Poland solidly supported Polish EU accession despite the fact that the PiS and PSL contained anti-EU factions. The League of Polish Families led the No campaign stressing the potential negative impact of EU accession and often resorting to less salient emotional and ideological themes that were unlikely to mobilise support beyond a relatively small hard core. For the League, accession would lead to the promotion of antiChristian values or to placing Poland's independence under threat, using slogans such as 'Yesterday Moscow, Tomorrow Brussels' (Szczerbiak, 2003:6). Self-Defence argued that it was against the unfavourable accession terms negotiated by the government and campaigned on the enigmatic slogan, 'The Choice is Yours'. In the June 2003 European Union accession referendum the officially recorded turnout in the referendum was 58.85 per cent of eligible voters (a 50 per cent turnout was required by the Polish Constitution for it to be valid), of whom 77.45 per cent cast a 'Yes' vote and 22.55 per cent a 'No'. In the campaign for the European Parliament elections in 2004 , which was generally dominated by domestic themes, the pro-EU Civic Platform (PO) won nearly twenty-five per cent of the vote, the Catholic-nationalist League of Polish Families more than fifteen per cent of the vote, Law and Justice favouring a strongly-intergovernmentalist vision of Europe polled $12.67 \%$ with the radical-populist Self-Defence, which had called for a complete re-negotiation of Polish accession terms finishing fourth on $10.87 \%$ of the vote. European issues played no discernable role in the parliamentary election campaign of 2005 . 
Alexs Szerzcbiak and Paul Taggart (2003:6) have argued that euroscepticism has been vaguely defined in conceptual terms and requires delineation between what they refer to as hard and soft Euroscepticism. They assert that hard Euroscepticism '...might be defined as a principled opposition to the project of European integration as embodied in the EU...' Party-based soft Euroscepticism is represented as '... when there is not a principled objection to the European integration project of transferring powers to a supranational body such as the EU, but there is opposition to the EU's current or future trajectory based on the further extension of competencies that the EU is planning to make...'. In this context, both the League of Polish Families (LPR) Self-Defence adopted a highly critical (if not completely hostile) approach towards the EU. While the Self Defence has advocated a policy-based or 'functional Eurorealism' particularly in its resistance to certain of the provisions of the Single Market, e.g., the sale of Polish land to foreigners and European Commission subsidies to Polish farmers, the League has displayed a more recognisably identity-based hard Euroscepticism. The PSL has also displayed an occasional 'functional Eurorealism' tendency based on similar policy concerns as the Self Defence. The emergence of Self Defence clearly jeopardises the PSL's core electoral constituency. The League has explicitly inclined towards a fundamental, principled objection to European integration as a threat to what it regards as Poland's newly-restored national sovereignty. The SLD and the PO are the most pro-EU political groupings in Poland and both worked vigourously to ensure a Yes vote in the 2003 Referendum on accession. The official PiS position was essentially supportive of Polish EU membership but favoured a 'Europe of nation states'. The SLD, PSL, Freedom Union, and the newly-formed Polish Social Democracy also achieved representation in the European Parliament elections in June 2004.

While the current PiS, LPR and Samoobrona coalition is widely perceived as the most Eurosceptic government in post-1989 Polish history, a recent study commissioned by the European Union Department of the Polish Ministry of Foreign Affairs has shown paradoxically that the percentage of Poles supporting integration is very high (CwiekKarpowicz,2006:2-4). According to the survey data, the greatest percentage of people supporting Polish membership in the EU can be found among supporters of the PO $(81 \%)$ and the SLD (72\%), the least - among those who vote for LPR and Samoobrona (45\% each). Those who are satisfied that Poland is a member of the EU are mainly of centre-right and centre-left political views ( $75 \%$ each), more rarely -those who place themselves on the right of the political spectrum $(62 \%)$. The same research study discovered 
that most Poles favour a highly integrated EU with strong institutions and closer cooperation among all Member States (69\%). Consequently, they support the idea of a common EU government (49\%), common armed forces $(51 \%)$ and an EU minister for common foreign policy (52\%). The idea of an EU constitution enjoys strong support - $68 \%$ of respondents believe that the European Union needs a constitution. It was further determined that among Poles with a positive attitude towards the process of European integration, the majority are urban, young people who have received a higher education. While a Eurobarometer survey in 2005 also determined that a majority of Poles $(63 \%)$ claim that their country has benefitted from EU membership, equally a majority of Poles (75\%) do not feel very involved in European affairs and trust in the European Commission and European Parliament had also declined. Importantly, the Eurobarometer 64 research data from 2005 found that it was not EU issues that preoccupied Polish voters. When asked to indicate the two most important problems confronting their country, Poles most frequently cited unemployment $(71 \%)$ and the healthcare system $(35 \%)$. When Poles were asked what goals should be given top priority in the coming years, the highest proportion of the poll mentioned the maintenance of order in the country (38\%). (Eurobarometer 64, 2005)

\section{Towards the 'Fourth Republic' Domestic Implications}

The current government led by the Law and Justice party, and its two coalition partners, Self-Defence and the League of Polish Families, has provoked considerable concern domestically and externally. Andrzej Lepper, the leader of Self-Defence, who openly admires the president of Belarus, Aleksander Lukashenko, is a deputy prime minister, with overall responsibility for agriculture and rural development. The League's leader, Roman Giertych, is now a deputy prime minister with responsibility for education. In May 2006, Roman Giertych strongly condemned the activities of the Polish non-governmental organization Campaign against Homophobia and in June 2006 supported the appointment of Piotr Farfal, a former far-right activist and former editor-in-chief of the Polish skinhead magazine Front, as Deputy Chairman of Poland's public television network. During the 2004 controversy surrounding Rocco Buttiglione (the conservative Italian nominee as European Commissioner for Justice, Freedom and Security ) the LPR deputies demanded the dissolution of the European parliament, believing that it was excessively under the influence of the homosexual lobby. When serving as mayor of Warsaw, President Lech Kaczynski attempted to ban Gay Pride marches in 2004 and 2005. During his presidential campaign, Kaczynski said that he would continue to 
ban gay demonstrations. The League of Polish Families has also demanded changes in the Polish penal code announcing a campaign to restore the death penalty in August 2006. In September 2006, the League confirmed that it will attempt to deprive the German minority in Poland of its electoral privileges in parliament. Germans constitute the largest ethnic minority in Poland accounting for almost 0.4 percent of the total population. At present, it has two representatives in the Parliament.

As for the Kaczynski's, they '....are proudly Polish and Catholic. They like law and order. They don't like gays, abortion, Russians or Germans, communists, football hooligans, or corrupt businessmen and politicians...' (Traynor, 2005). For Halliday (2006) '...the Kaczynski brothers are...unashamed about exploiting popular fears and, given their positions, dangerous'. The PiS are, indeed, populists -- and they project their Catholicnationalist worldview energetically. When serving as mayor of Warsaw, President Lech Kaczynski attempted to ban Gay Pride marches in 2004 and 2005. During his presidential campaign, Kaczynski said that he would continue to ban gay demonstrations. Poland is a socially conservative Roman Catholic country, so while it is not problematic in itself that culturally conservative politicians should represent their voters' sentiments and prejudices on homosexuality for example, many of these positions run counter to the provisions of EU anti-discrimination directives. In June 2006, the European Parliament in Strasbourg passed a resolution condemning the growing signs of racism and anti-Semitism in Poland and elsewhere. More disturbing, however, are the facts that the Law and Justice Party itself has effectively appropriated the Catholic fundamentalist and nationalist ideology of the LPR and that Radio Maryja, the notorious ultra-nationalistic station, has become virtually the main medium for the promotion of government policy. When the PiS emerged as the single largest party following the parliamentary elections, Jaroslaw Kaczynski declined the office of prime minister, believing that his nomination would endanger his brother's chances in the presidential election and the post went to Kazimierz Marcinkiewicz. By July 2006, however, Jarosław Kaczynski had succeeded in becoming become prime minister.

The Law and Justice- led government believe that the Polish Third Republic - as the post-1989 Polish constitution is known, has become corrupted and morally bankrupted by the uklad. The uklad constitutes a mafia-style system of secretive arrangements between what is perceived as a 'rotten establishment'-liberal and left politicians, civil servants, the media, the judiciary and the secret service, who have used the transition period to enrich themselves and dominate the country during the post-communist 
transition. See Lucas (May 2006) and Gentle (2006) for a more detailed treatment of the uklad phenomenon. What is needed, according to government supporters is the removal of senior personnel in all levels of public life, and a new constitution, which would usher in Poland's Fourth Republic, a new Poland. Speaking at the PiS' second party convention in June 2006 PiS chairman Jaroslawl Kaczynski declaimed:

\section{'...in the years following 1989 the Polish state has become} a "postcommunist monster" characterized by pathologies inherited from the previous system. Kaczynski stated that a system was created in Poland that controlled different kinds of institutions, especially those dealing with the distribution of goods. He judged this system as unfair, a system under which economic growth was paid for with unemployment and poverty'. (cited in Warsaw Voice, 7th June 2006)

The Law and Justice party has prepared a draft of a broad vetting law that would vet 400,000 posts in the public sector, for contacts or collaboration with the old communist security services (Traynor 2006). Similarly, the liberal PO has also argued that the need for a strong state is critically important in Poland's political development. 'The main problem is a weak executive, institutional incompetence and an inability to implement law,' says Jan Rokita, deputy leader of Citizen's Platform... who wants a 'smaller, cheaper, more brutal, firm, hard state, with rigorous laws, rigorously applied' (Cited in Maryniak, 2003). The government has also commited itself to purging the Polish intelligence services of communist era elements. The Military Information Service (WSI) was disbanded on September 30th 2006 and succeeded by the creation of separate military intelligence and counterintelligence services and verification of WSI military intelligence and counterintelligence officers. In September 2006, the ruling Law and Justice Party proposed legislation on 'decommunisation' that would legally prohibit former communist 'aparatchiks' from holding elected office or nominated government positions. In February 2007, the Polish Senate finalised its work on the new vetting law, which will force all public figures to reveal their past relationships with the former communist regime.

The Law and Justice Party abruptly ended their coalition with the leftist Samoobrona party in late September 2006 after an acrimonious dispute over the 2007 state budget and Samoobrona's criticism of Prime Minister Jarosław Kaczynski decision to send additional troops to Afghanistan without consulting Deputy Prime Minister Lepper. Prime Minister 
Kaczynski said that he would call an early election if he was unable to attract the support of a sizeable contingent of defectors from Lepper's parliamentary grouping or find new coalition partners, probably from the Polish Peasant Party (PSL). After a senior aide to the Prime Minister was filmed secretly offering financial and political inducements to persuade a Self Defence MP to defect to Law and Justice, Jaroslaw Kalinowski, leader of the Peasants' Party ruled out the possibility of forming a coalition with PiS and accused the government of corruption. On 24th September 2006, the National Council of the opposition Civic Platform (PO) appealed for the dissolution of parliament and early elections. On October 17th 2006, Law and Justice finally reached an agreement with Self Defence and the League of Polish Families to vote against the holding of new elections and to ensure the continuation of the coalition. The local government elections in November 2006 saw the Law and Justice Party managing to retain a marginal lead in the popular vote nationwide over the Civic Platform. The Law and Justice Party won most county and municipality councils while the Civic Platform won most provincial assemblies and the won the mayoral election in Warsaw. Samoobrona and LPR both experienced a major loss of support in the elections. It is predicted that in the event of parliamentary elections neither PiS nor PO could currently secure a majority that would enable them to govern without coalition partners.

\subsection{Polish Foreign Policy: Mistrust and Divergence from the EU?}

According to Federico Bordonaro (2005) the Polish elections in 2005 will not result in significant changes in Warsaw's foreign policy, although the most important bilateral relations will increasingly be those with the United States. In terms of European Union developments, Poland's relations with the EU are likely to be more turbulent. President Kaczynski has emphasized Poland's intention to defend its national sovereignty within the EU, and that Poland would not hesitate to stand alone in order to protect its national interests. In his first speech to parliament as prime minister in July 2006, Jaroslaw Kaczynski affirmed Poland's desire for integration with NATO and the EU whilst also stressing the right 'to not give up Polish positions.' Furthermore, the PiS party also explicitly warned against an immediate switch to the euro which stands in contrast to the PO position. President Kaczynski has observed that 'Getting rid of one's own currency is a very serious limitation of one's own sovereignty.' ('Polish Regions', 2006) President Kaczynski had also expressed strong opposition to the proposed EU constitution: 
'...The constitution may radically change Poland's status in the world. It isn't true that it merely puts in order the existing legal framework. It's a new entity. It creates something of a European state. It introduces a principle of superiority over the Polish constitution and all other national constitutions. There's an underlying idea in this document it sets a path towards the elimination of nation states and the emergence of a European state in the strictest sense of the word. I am definitely opposed to it... Realistically, however, we have to collaborate above all with those countries that want more autonomy within the EU, such as the UK or Denmark'. ('Strong and Moral State', 2006)

In March 2006, President Kaczynski told the German daily Die Welt. '...My opinion of the EU is the following: A super state which polarizes countries' areas of competence but which at the same time is rather helpless because it only has a symbolic budget...The EU is an artificial creation.' (cited in 'Polish President Lashes Out', 2006). The government's commitment to expand welfare spending and the state role in the economy have also disturbed foreign investors and the European Commission. For instance, in an effort to assist small-business development, the government has proposed a plan that would halt the construction of large, (essentially foreign-owned) supermarkets and prevent existing ones from opening on Sundays.Unlike the PO, the PiS is state-interventionist and antiprivatisation, favours a strong state-provided health service and opposes flat taxes. The Law and Justice Party also set up a parliamentary commission in March 2006 to scrutinize both the sale of certain Polish banks to foreign owners after the fall of communism and to investigate the role played by the Polish Central Bank in key privatisations since 1989. Furthermore, in June 2006 the European Commission decided to open formal inquiries regarding the restructuring of Polish shipyards. In August 2006 the Commission demanded a plan from Poland on restructuring without which the commission would not confirm state aid for shipyards in financial difficulties (European Commission, 2006). On his first visit to the European Commission in late August 2006 prime minister Jaroslaw Kaczynski announced Warsaw's intention to submit its proposals for a new charter to the German EU presidency in early 2007 that would seek to replace the proposed EU constitution text. Kaczynski also warned that any new EU constitution must offer Warsaw real influence in EU-decision making. The Polish prime minister also defended Poland's commitment to liberal, European values and tolerance ('Gay-friendly Poland', 2006) 
Essentially, the government's foreign policy is characterized by a profound mistrust of Russia and Germany, which are inevitably perceived as geopolitical rivals by Warsaw. In September 2005, Germany and Russia signed an agreement on the construction of a $5 \mathrm{bn}$ gas pipeline beneath the Baltic Sea, linking Russia directly with Germany and about which Waraw had never been consulted. Radoslaw Sikorski, the Polish defence minister, accused Berlin of hypocrisy, in its advocating of common EU foreign, security, and energy policies while failing to consult EU allies.

Poland's dependence on Russian energy, particularly gas, is a serious long-term problem, especially if Moscow decides to suspend energy supplies to its former satellite states without endangering its lucrative and politically important energy supplies to western Europe. 'Poland has a particular sensitivity to corridors and deals above our head,' Mr Sikorski told a transatlantic security conference in Brussels. 'That was the MolotovRibbentrop tradition. That was the 20th century. We don't want any repetition of that,' he said (Traynor May 1, 2006). In June 2006 Prime Minister Kazimierz Marcinkiewicz criticised the Russian-German agreement to lay a gas pipeline under the Baltic Sea. In Brussels, the head of the Polish government, declared that Poland would ensure that the European Union never supports the project. 'The EU should support ventures that help everybody and are aimed against no one,' Marcinkiewicz stressed ('Poland again criticises', 2006). President Kaczynski has pointed to the ways in which:

'...The Russians can be expected to carry out policies aimed at regaining their influence in Poland. I'm talking here about gas, oil, and so on. The Russians want this to be their zone of influence again, though of course on a different basis than in the past. They don't want full domination but rather an ability to exert substantial influence...' ('Strong and Moral State', 2006)

Poland currently plans to improve its energy security by diversifying the sources of energy supplies on which it is dependent (currently, Poland imports over 90 percent of its oil and 60 of gas from Russia). The country aims to increase imports of oil via the Ukrainian Odessa Brody oil pipeline to Plock in Poland and deliveries of Norwegian natural gas to Poland are also to rise. In February 2006, Poland submitted a proposal to all NATO and European Union countries to create an 'energy security pact' providing mutual support to members in the event of an energy crisis. Poland is also reviewing an offer from Lithuania to co-operate in the building of a new 
nuclear reactor at the Ignalina facility in a joint project with Estonia and Latvia. Tensions also exist between Russia and Poland over Moscow's decision to impose an embargo on the import of meat and individual categories of meat products from Poland in November 2005. The Russians claim that they had discovered numerous cases where Polish meat was smuggled into Russia on the basis of forged veterinary certificate and violations of phytosanitary requirements. Polish officials accept that violations may have occurred but argue that the Russian response is an overreaction and that the Russian embargo is contary to the 1997 RussianEU agreement on partnership and cooperation that bans commercial restrictions. Consequently, in November 2006 Poland vetoed the opening of EU negotiations with Russia on a new Partnership and Cooperation Agreement to replace the current agreement which expires at the end of next year. The planned new partnership deal was to have centred on securing improved EU access to Russian energy resources. At the time, Germany's deputy foreign minister, Gernot Erler, said Poland was isolating itself by refusing to remove its veto on opening the talks. This was the first ocassion on which one of the 2004 CEE entrants to the EU had exercised a veto over such a major EU agreement. For its part, Russia has also been infuriated by Poland's support for Ukrainian and Georgian efforts to enter the EU and NATO as well as Polish consultations with the United States on deployment of U.S. anti-missile defense systems on Polish territory.

The Polish-German reconciliation of the 1990s, has perceptibly weakened since the establishment of the Law and Justice Party-led government.. Poland has reacted negatively to attempts by the Prussian Trust to secure compensation for property lost by Germans at the end of the Second World War in what is now Polish territory and also to a controversial exhibition that opened in Berlin in August 2006 which focused on the large-scale expulsion of Germans from eastern parts of the Third Reich after World War Two. Polish prime minister Jaroslaw Kaczynski described the exhibition as 'a bad, worrying and sad event' and said: 'it is not doing anything positive for Poland, Germany or Europe.' He said it was '... an attempt to relativize the history of World War II," and that. 'It's important to remember who the murderers were and who the victims' ('Berlin Exhibition', 2006).

According to Piotr Maciej Kaczynski (2005:4-5) as the biggest EU member from the 2004 accession wave, Poland will attempt to retain its leading role among the recent EU entrants. For the Law and Justice Party, the Visegrad Group (the Czech Republic, Hungary and Slovkia) and Lithuania will potentially be its closest partners. Core Polish interests are 
focused on maintaining the Nice system of decision-making in the Council and strengthening the CFSP, especially its Eastern European dimension. Additionally, Piotr Maciej Kaczynski (2005) points out that Warsaw will probably try again to cause the weakening of Belarus President Alexander Lukashenko's pro-Russian rule, and to facilitate Moldova's integration into the EU. The insular mentality of Poland's leaders has already impacted on the regime's relations with EU institutions. In July 2006, the former director of EU affairs in the Polish foreign ministry, Pawel Swieboda, commented that the present Polish government:

'...is focused on internal politics and EU affairs are a distant question. They don't adequately identify the impact of European policies on national politics... is not pro-active, getting involved at an early-stage in the decision-making process. It is defensive. It reacts to events. There won't be any catastrophe, but Poland will not be a country with any real power of action' (cited in Rettman, 2006)

Grabbe (2004) has argued that the obvious danger for Poland is that it will routinely adopt a stance of 'no compromise' in its relations with the EUand thus exert as little influence on the EU's development as Britain did during the 1980s and 1990s. Poland is, it would seem, 'increasingly playing the role of the introspective and unreliable' EU partner (Connolly, 2006). It would be difficult to refute entirely the notion that '...Unstable and populist governments in the new democracies offer a poor advertisement for continued EU expansion...' (Lucas July 2006).

\section{Conclusions}

With some justification, Zdzislaw Krasnodebski observed in 2004 that that while Poles can congratulate themselves on building a democratic system, '...their success is only partial. The quality of Polish democracy is worsening, while the opposite was expected...'. Perhaps, the problem with the Polish case is not the overtly undemocratic character of the postcommunist transition's legacies or the disloyalty of the old elites toward the new regime. Rather, as Munck and Skalnik Leff (1999:261-2) have observed, the residual power of the old elites and the anti authoritarian coalition's loss of identity have culminated in the adoption of institutional rules that are not necessarily the best ones for ensuring democratization. To paraphrase Irena Maryniak (2003), the Polish electorate has clearly been radicalized by both a sense of injustice about the impact of the systemic economic reforms introduced in the early 1990s as well as a pervasive resentment towards the people who found a place for themselves and 
profited from the post-1989 settlement- often the same priviledged ruling class or "uklad" who ran things under communism. It is for this reason that the ruling coalition, and the Law and Justice Party in particular have been able to maintain the support of most voters on the urgent need for an alternative, Polish model of modernisation that will erase the corruption and crony capitalism of the post-communist nomenklatura.

With a population of 38.6 million, Poland was inevitably going to be one of the more difficult of the new CEEC states for the EU to digest. The electoral success of Poland's new Eurosceptic, socially conservative and intensely Catholic political elite poses a not inconsiderable challenge to the future direction of the European integration project itself. Poland now intends to champion the cause of the 2004 EU accession states, to counterbalance possible German or Russian hegemony in Central and Eastern Europe and to oppose the proposed EU constitution. It will also reject any reform of Common Agriculture Policy funding that it views as failing to take into account the requirements of Central European farmers. A tough line in negotiations is to be expected especially on further EU enlargement (the PiS and its coalition partners are technically against Turkish membership of the EU) and support for an increase in the EU budget.

The fact remains that the Kaczynski duopoly has embarked on '...a political project ... about how the elites function, how society is constructed, how power is exercised and distributed in this country,' as Adam Lipinski, a political aide to the prime minister has put it. 'The democratic system is not threatened in any way. The only thing that is threatened is the status quo and the elites that built the present system' (Traynor, 2006). In their attempt to fashion a 'moral state' and passion for conspiracy theories, the current generation of Polish populists should avoid, either implicitly or explicitly, endangering the gains generated by Poland's democratisation and economic reform process, damaging the quality of the country's strategic relationship with the European Union or failing to play an active role in EU decisionmaking processes.. 


\section{List of Major Political Formations in Poland}

Prawo i Sprawiedliwosc (PiS, Law and Justice)

Samoobrona Rzeczypospolitej Polskiej ( SRP, Self-Defence of the Republic of Poland)

Platforma Obywatelska (PO, Civic Platform)

Sojusz Lewicy Demokratycznej (SLD, Democratic Left Alliance)

Unia Wolnosci (UW, Freedom Union)

Unia Pracy (UP, Labor Union)

Polskie Stronnictwo Ludowe (PSL, Polish Peasants' Party)

Liga Polskich Rodzin (LPR, League of Polish Families)

Akcja Wyborcza Solidarnosci (AWS, Electoral Action Solidarity)

\section{References:}

Berlin Exhibition on Post-War Expulsions opens Amid Protests. Deutsche Welle, (2006, August 11). Retrieved August 20, 2006, from http://www.dw-world.de/dw/article/0,2144,2129308,00.html

Bordonaro, F. (2005). Poland's Right-ward Turn and the Significance for Europe. Rome : The Power and Interest News report. Retrieved June 11, 2006, from http://www.pinr.com/report.php?ac=view_printable\& report_id=373\&language_id=1

Cave, A. (2000). Five Percent Solution. Central Europe Review, 2, (27), Retrieved June 10, 2006, from http://www.ce-review.org/00/27/cave 27.html

Connolly, K. (2006). How the Kaczynski twins are dragging Poland back in time. Daily Telegraph. Retrieved September 6, 2006, from http://www.telegraph.co.uk/opinion/main.jhtml?xml=/opinion/ 2006/08/09/do0904.xml.

Cwiek-Karpowicz, J. (2006). Polish public opinion on the European Union and the Constitutional Treaty Survey Report. Warsaw: Instytut Spraw Publicznych (Institute of Public Affairs), May 2006. Retrieved June 15, 2006, from www.isp.org.pl.

Dabrowski, M., Rohozynsky, O., and Sinitsina, I. (2004). Poland and the Russian Federation: A Comparative Study of Growth and Poverty. 
World Bank: Shanghai Poverty Conference. Retrieved June 1, 2006, from http://info.worldbank.org/etools/docs/reducingpoverty/case/26/ summary/case-summ-Poland-CountryCase.pdf.

Dahrendorf, R. (1997). After 1989: Morals, Revolution and Civil Society.

New York: St. Martin's Press.

European Commission (2005). Eurobarometer 64 Public Opinion in the European Union Autumn 2005 National Report Executive Summary Poland. Brussels: European Commission.

European Commission (2006). State aid: restructuring of Polish shipyards under Commission scrutiny. Brussels: European Commission.

Gay-friendly Poland wants more EU clout, prime minister says. EUobserver.com, (2006). Retrieved September 1, 2006, from http://euobserver.com/9/22300

Gentle, P. (2006). A New Nomenklatura. Radio Polonia, Retrieved June 22, 2006, from http://www.polskieradio.pl/polonia/article.asp?tId=38096 $\& \mathrm{j}=2$

Grabbe, H. (2004). Poland: The EUs New Awkward Partner. Centre for European Reform Bulletin, 34,February/March 2004. Retrieved June 20 2006, from www.cer.org.uk/articles/grabbe_iht_16may03.html.

Grabbe, H.(2006). The EU's Transformative Power Europeanization through Conditionality in Central and Eastern Europe. Basingstoke: Palgrave Macmillan.

Grabowska, M. and Szawiel, T. (2001). Budowanie demokracji. Podziaty spoteczne, partie polityczne $i$ społeczeńswto obywatelskie $w$ postkomunistycznej Polsce [Constructing democracy: social divisions, political parties and civil society in postcommunist Poland], Warsaw: PWN.

Halliday, F. (2006, September). Warsaw's populist twins. OpenDemocracy.net. Retrieved 9th September 2006 from http://www.opendemocracy.net/globalization/poland_twins_3871.jsp.

Holmes, L.(1998). Towards a stabilization of party systems in the postCommunist countries. European Review, 6(2).

International Republican Institute (1997). Poland's Parliamentary Elections Political Situation Update. Washington, DC: International Republican Institute. Retrieved May 17, 2006, from http://www.iri.org/pub.asp? $\mathrm{id}=9884059500$. 
Jasiewicz, K. and Jasiewicz-Betkiewicz, A. (2004). Poland The June 2003 European Union accession referendum. Political Data Yearbook 2003, special issue of the European Journal of Political Research, 43 (7-8). Retrieved May 10 2006, from http:/home.wlu.edu/ jasiewiczk/ ejpr_207.pdf.

Kaczynski, P. M. (2005). What will the new Polish Government's Policy be in Europe after the parliamentary and presidential elections? Warsaw: Instytut Spraw Publicznych (Insitute of Public Affairs).

Klich, Jacek (1997). Private Sector and Systemic Changes in the Polish Economy:1990 - 1995. Krakow: Centre for European Studies: Jagiellonian University, Retrieved June 3, 2006, from http://www.ces.uj.edu.pl/klich/systemic.htm.

Kochanowicz, Jacek , Kozarzewski, Piotr and Woodward, R.(2005). Understanding Reform: The Case of Poland. Warsaw: Center for Social and Economic Research.

Kość, Wojtek (2001). A Surprising Alliance The birth of a liberalconservative platform in Poland. Central Europe Review, 3(4). Retrieved May 10, 2006, from http://www.ce-review.org/01/4/ kosc4.html.

Krasnodebski, Zdzislaw (2004). Demokracja peryferii (Democracy at the Periphery) The Samartian Review, 24 (2). Retrieved June 10, 2006, from http://www.ruf.rice.edu/\%7Esarmatia/404/242kras.html.

Lucas, E. (2006). Poland's present rulers are very different from all their predecessors The Economist. Retrieved May 12, 2006, from http://edwardlucas.blogspot.com/2006/05/poland-survey-chapter-2politics.html.

Lucas, E. (2006). The shoelace handicapThe Economist. Retrieved August 12, 2006, from http://edwardlucas.blogspot.com/2006/07/shoelacehandicap.html.

Majman, S. (2000). The Night After. Warsaw Voice. Retrieved 10th May, 2006 from http://www.warsawvoice.pl/archiwum.phtml/12848/.

Maryniak , I. (2003). Goodbye Solidarity...And Welcome to Poland's New Breed Democrats. Eurozine.com. Retrieved June 12, 2006 from http://www.eurozine.com/articles/2002-03-28-maryniak-en.html.

Matraszek, M. (2005). Victories, Defeats, Reconfigurations and Reinventions of the Polish Right'. In P. Ucen and J. E. Suratchok (Eds.), Why We Lost: Explaining the Rise and Fall of the Centre-Right Parties 
in Central Europe, 1996-2002 (pp.87-101). Bratislava: International

Republican Institute.

Meny, Y. and Surel, Y. (2002). The Constitutive Ambiguity of Populism.In Y. Meny and Y. Surel (Eds.). Democracies and the Populist Challenge. NewYork: Palgrave.

Millerd, F. (2002). Elections in Poland 2001: Party Chaos and Electoral Manipt:lation. Paper prepared for the British Association of Slavonic and East European Studies Annual Conference, Cambridge, 8 April 2002.

Ministry of Foreign Affairs of Poland. (2002). Information by the Minister of Foreign Affairs on the fundamental directions of the Polish foreign policy (presented at the 16th Session of the Seim on March 14th, 2002). Retrieved June 10, 2006, from http://www.mfa.gov.pl/,Ministers,Annual, Address,2002,2135.html.

Mudde, C. (2004) EU Accession and a New Populist Centre-Periphery Cleavage in Central and Eastern Europe. Centre for European Studies Central and Eastern Europe Working Paper No:62. Revised Version of paper presented at the Conference "Dilemas of Europeanization: Politics and Society in Eastern and Central Europe after EU Enlargement" Harvard University , December 5-6, 2003. Retrieved September 9, 2006, from http://www.ces.fas.harvard.edu/publications/_docs/pdfs/Mudde.pdf.

Munck, G. L. and Skalnik Leff, C. (1999). Modes of Transition and Democratization: South America and Eastern Europe in Comparative Perspective. In Lisa Anderson (Ed.) Transitions to Democracy. Irvington, New York: Columbia University Press.

Poland again criticises German-Russian Pipeline in the Baltic (2006). Radio Polonia, (2006, June 16). Retrieved August 25, 2006, from http://www.polskieradio.pl/polonia/article asp?tId=37930\&j=2.

Polish President Lashes Out at "Artificial" EU in Berlin (2006, March 9) Deutsche Welle. Retrieved August 19, 2006, from http://www.dwworld.de/dw/article/0,2144,1929092,00.html.

Polish Regions Poorest in EU (2006). Radio Polonia (2006, May 19). Retrieved August 25, 2006, from http://www.polskieradio.pl/ polonia/article.asp?tId $=36732 \& \mathrm{j}=2$.

Plonka, B. (2004). Poland's Transformation: A work in Progress (review) The Samartian Review April 2004, 24 (2), Retrieved June 26, 2006, from http://www.ruf.rice.edu/\%7Esarmatia/404/242plonk.html. 
Pop-Eleches, Gr. (2001). Radicalization or Protest Vote? Explaining the Rise of Unorthodox Parties in Eastern Europe. Paper presented at the Annual Meeting of the American Political Science Association, San Francisco, August 30-September 2, 2001.

Rettman, A. (2006). Poland losing grip on Europe, Polish diplomat warns. EUobserver.com. Retrieved August 20, 2006, from http://euobserver.com/?aid=22191.

Riishoj, S. (2005). Europeanization and Euroscepticism- experiences from Poland and the Czech Republic. International Council for Central and Eastern European Studies Conference, Berlin, August 2005.

Schrijvers, A. (2004). When outsiders become insiders. An analysis of the accession negotiations between Poland and the EU. Reluctant new Europeans in the club? Second Pan European Conference Standing Group on EU Politics Bologna, 24-26 June 2004.

Second PiS Convention. (2006, June, 7 ). Warsaw Voice. Retrieved August 11, 2006, from http://www.warsawvoice.pl/view/11593.

Strong and Moral State: Lech Kaczynski Speaks on His Presidential Plans (2006). Rzeczpospolita p. A5-A7, and 21 March 2006 Rzeczpospolita p. A2. English Translation. Retrieved July10, 2006, from http://www.ewarsaw.pl/new/index.php?dzial=aktualnosci\&ak_id $=438 \&$ kat $=1$.

Surdej, A. (2005). Sources of Corruption in Post-Communist Poland. In Political Corruption in Poland. Bremen: Forschungsstelle Osteuropa Bremen Arbeitspapiere und Materialien No:65.

Szczerbiak, A. (2001). The Political Outlook and the European Issue. Helen Wallace and Alan Mayhew (eds.) Poland: A Partnership Profile. Brighton: Sussex European Institute, Policy Paper 4/2001-04-09.

Szczerbiak, A. (2002). The Polttical Context of EU Accession in Poland. London: The Royal Institute of International Affairs.

Szczerbiak, A. (2003). Referendum briefing No 5. The Polish EU Accession Referendum 7-8 June 2003. Brighton: Sussex European Institute.

Szczerbiak, A. and Taggart, P. (2003). Theorising Party-Based Euroscepticism: Problems of Definition, Measurement and Causality. Brighton: Sussex European Institute, SEI Working Paper No. 69. 
Szczerbiak, Aleks, (2006). 'Social Poland' defeats 'Liberal Poland'?: the September-October 2005 Polish Parliamentary and Presidential Elections. Brighton: Sussex European Institute SEI Working Paper No.86.

Traynor, I. (2005). The twins who would take over Poland. The Guardian. Retrieved September 25, 2006, from http://www. guardian.co.uk/eu/story/0,1569245,00.html.

Traynor, I. (2006). Poland recalls Hitler-Stalin pact amid fears over pipeline. The Guardian. Retrieved September 25, 2006, from http://www. guardian.co.uk/eu/story/0,,1765054,00.html.

Traynor, I. (2006). Ambitious, eccentric - Polish twins prescribe a dose of harsh reality. The Guardian. Retrieved September 25, 2006, from http://www.guardian.co.uk/international/story/0,186 2458,00.html.

Trzaskowski, R. (2002). From Candidate to Member State: Poland and the future of the EU. Paris: Institute for Strategic Studies, Occasional Papers No37.

Zalega, D. (2006) Poland's rightwards shift. Le Monde Diplomatique (English Edition). Retrieved September 13, 2006, from http://mondediplo.com/2006/09/15poland. 